\title{
ANTINOMI DALAM PENERAPAN ASAS LEGALITAS \\ DALAM PROSES PENEMUAN HUKUM
}

\author{
E. Nurhaini Butarbutar \\ Dosen Hukum Acara Fakultas Hukum Unika St Thomas Medan \\ (e-mail : elisa_nurhaini@yahoo.com)
}

\begin{abstract}
Abstrak
Penerapan asas legalitas sering menimbulkan antinomi dengan asas mengadili menurut hukum, asas rechtweigering dan asas kebebasan hakim. Namun sebagai asas, semua asas tersebut saling melengkapi dalam penerapannya. Dalam menerapkan asas legalitas, hakim tetap memperhatikan kepastian hukum, sedangkan asas hakim mengadili menurut hukum, dijalankan dengan mengingat bahwa undang-undang dibuat untuk melindungi kepentingan manusia, sedangkan kepentingan manusia itu selalu berkembang maka hukum juga harus berkembang sehingga selalu dapat melindungi kepentingan manusia. Dengan kebebasan hakim, maka hakim dapat selalu melengkapi atau menafsirkan undang-undang sehingga putusannya dirasakan adil (Einzalfallgerechtigkeit) dan bermanfaat.
\end{abstract}

Kata Kunci : Antinomi, penerapan, asas legalitas, penemuan hukum

\section{Abstract}

The applying of the principle of legality often generate antinomy with principle of judge according to law, principle of rechtweigering and principle of freedom of judge. But, as the principle, they are each other equiping in applying of him. In applying of principle of legality, judge remain to pay attention rule of law, while the principle of judge according to law, run by in view of law made to protect importance of human being, while importance of that human being always expand hence law also have to expand so that always can protect importance of human being. With freedom of judge, hence judge earn always equip or interpret of law so that the decision of felt fair (Einzalfallgerechtigkeit) and useful.

Keywords :, Antinomy, the applying, the principle of legality, law finding process.

A. Pendahuluan

Dalam Pasal 6 ayat (1) UU Nomor 48 Tahun 2009 tentang Kekuasaan Kehakiman, untuk selanjutnya akan disebut UU Kekuasaan Kehakiman ditentukan bahwa tidak seorangpun dapat dihadapkan di depan pengadilan selain daripada yang ditentukan oleh undang-undang. Pasal 6 ayat (1) UU Kekuasaan Kehakiman ini

Yustisia Vol.1 No.1 Januari - April 2012 mengandung asas legalitas, yang menginginkan bahwa setiap orang yang dihadapkan ke pengadilan haruslah orang yang dianggap telah melanggar undang-undang, dalam arti jika orang tersebut melakukan perbuatan yang dilarang oleh undang-undang.

Pada umumnya asas legalitas ini, lebih dikenal dalam proses perkara pidana, karena ketentuan tersebut jelas 
diatur dalam Pasal 1 ayat (1) KUHP dikenal dengan asas nullum delictum nulla poena sine praevia lege poenali, yaitu asas yang mengatakan bahwa tiada suatu perbuatan dapat dipidana kecuali atas kekuatan aturan pidana dalam perundang-undangan yang telah ada sebelum perbuatan dilakukan. Dengan adanya asas legalitas tersebut, maka terdapat tiga hal penting yang harus diperhatikan dalam penerapan hukum pidana (Prodjodikoro, 1986 : 39), yaitu, adanya sanksi pidana (straft sanctie) yang disebut dalam KUHP hanya dapat dikenakan pada pelaku pidana yang telah ditentukan sebelumnya dalam undangundang, hukum pidana tersebut tidak boleh berlaku surut dan dalam penerapannya dilarang melakukan analogi.

Kemudian Pasal 1 KUHAP menentukan bahwa hukum acara pidana hanya dijalankan berdasarkan cara yang ditentukan oleh undang-undang, terutama yang menyangkut hak asasi manusia, yaitu penangkapan, penahanan, penggeladahan dan penyitaan. Hal ini berarti, bahwa dalam sistem peradilan pidana, hakim dilarang untuk mengadili suatu perbuatan yang belum diatur dalam perundang-undangan.

Di sisi lain Pasal 4 ayat (1) UU Kekuasaan Kehakiman, menentukan agar pengadilan mengadili menurut hukum. Antara asas legalitas dengan ketentuan Pasal 4 ayat (1) UU Kekuasaan Kehakiman yang mengandung asas mengadili menurut hukum terdapat pertentangan atau antinomi karena pengertian menurut hukum dalam Pasal 4 ayat (1) UU Kekuasaan Kehakiman lebih luas dari pengertian menurut undang-undang.

Pengertian "menurut hukum" lebih membuka peluang bagi hakim untuk melaksanakan kebebasannya

Yustisia Vol.1 No.1 Januari - April 2012 untuk menemukan hukum melalui analogi dan atau interpretasi, dengan mengingat bahwa undang-undang bukanlah satu-satunya sumber hukum dalam sistem hukum Indonesia, sebaliknya pengertian "menurut undangundang", lebih membatasi kebebasan hakim dalam mengadili.

Menurut asas mengadili menurut hukum ini, hakim dalam mengadili suatu perkara harus sesuai dengan hukum yang berlaku baik hukum tertulis maupun hukum tidak tertulis, sedangkan asas legalitas mengharuskan hakim mengadili sesuai dengan undang-undang, dan dilarang mengadili peristiwa yang tidak atau belum diatur dalam undang-undang. Asas legalitas juga bertentangan dengan asas rechtweigering yang terkandung dalam Pasal 10 ayat (1) UU Kekuasaan Kehakiman yaitu asas yang melarang hakim untuk menolak memeriksa, mengadili dan memutuskan suatu perkara yang diajukan kepadanya dengan dalih hukumnya tidak ada atau tidak jelas. Di samping itu, bertentangan dengan asas kebebasan hakim yang merupakan salah satu prinsip penting dalam suatu negara hukum.

Menurut Pasal 1 ayat (3) Perubahan Ketiga UUD 1945, Negara Indonesia adalah negara hukum. Dengan asas legalitas yang tersebut, seolah-olah kebebasan hakim dalam penyelenggaraan kekuasaan kehakiman di Indonesia, dibatasi yang tentu saja merupakan pelanggaran terhadap prinsip dari suatu negara hukum yang sudah ditentukan dalam konstitusi.

Asas legalitas yang ditentukan dalam Pasal 6 ayat (1) UU Kekuasaan Kehakiman menginginkan agar setiap orang yang dihadapkan ke pengadilan haruslah orang yang dianggap telah melanggar undang-undang. Jika dicermati asas legalitas yang dimaksud 
dalam ketentuan Pasal 6 ayat (1) tersebut, ada dua kemungkinan yang terjadi, yaitu kemungkinan pertama, bahwa seseorang tidak sampai dihadapkan ke pengadilan walaupun dianggap sudah melanggar kepentingan umum tetapi karena undang-undang tidak jelas atau belum mengatur perbuatan tersebut. Kemungkinan kedua, seseorang tersebut sudah diajukan ke pengadilan tetapi hakimlah yang menilai apakah perbuatan tersebut melanggar undang-undang atau tidak.

Dalam tulisan ini yang akan dibahas adalah penerapan asas legalitas dengan kemungkinan yang kedua, yaitu penerapan asas legalitas dalam proses penemuan hukum oleh hakim di pengadilan. Dalam tulisan ini akan dikemukakan bagaimana penyelesaian antinomi dalam penerapan asas legalitas dengan asas hukum acara lainnya, yaitu asas mengadili menurut hukum, asas rechtsweigering dan asas kebebasan hakim. Sebagai suatu asas, keempat asas hukum umum dalam beracara tersebut, harus berjalan secara bersama-sama, meskipun dalam penerapannya terjadi konflik atau antinomi sehingga tujuan dari peradilan itu dapat tercapai, yaitu menegakkan kembali hukum akibat adanya pelanggaran hukum.

\section{B. Sifat dan Fungsi Asas serta Antinomi dalam Penerapannya}

Asas hukum diartikan sebagai pikiran dasar yang terdapat di balik suatu peraturan konkret. Sifat asas adalah abstrak, sehingga menyebabkan asas tidak dapat secara langsung diterapkan terhadap peristiwa konkrit. Realisasi hukum menurut Mertokusumo (2007 : 11) terjadi dalam tiga tahap, yaitu asas, peraturan hukum konkret dan putusan hakim. Dengan demikian, menurut Asser dalam Hartono (1992 : 86) tidak ada hukum yang dapat dimengerti tanpa asas-asas hukum.

Asas hukum dapat dibedakan menjadi asas hukum umum dan asas hukum khusus. Asas hukum umum merupakan asas hukum yang berlaku pada seluruh bidang hukum. Pada umumnya asas-asas hukum yang diatur dalam UU Kekuasaan Kehakiman berlaku secara umum, baik perkara perdata, perkara pidana dan perkara tata usaha negara, seperti asas legalitas dalam Pasal 6 ayat (1) UU Kekuasaan Kehakiman dan asas rechtweigering yang terkandung dalam Pasal 10 ayat (1) UU Kekuasaan Kehakiman. Asas hukum khusus, yaitu asas hukum yang berlaku pada satu bidang hukum saja, misalnya asas hukum yang dituangkan dalam KUH Perdata, asas hukum dalam KUH Pidana, asas hukum dalam Hukum Acara Pidana dan Hukum Acara Perdata.

Sebagai asas umum hukum acara, maka asas legalitas dalam Pasal 6 ayat (1) UU Kekuasaan Kehakiman, berlaku dalam setiap proses berperkara di pengadilan, baik perkara perdata, perkara pidana, maupun perkara tata usaha negara. Meskipun asas legalitas lebih dikenal dalam perkara pidana karena asas legalitas kembali dituangkan dalam Pasal 1 ayat (1) KUHP dan KUHAP sebagai hukum beracara pidana di pengadilan.

Fungsi asas hukum dalam hukum adalah melengkapi sistem hukum, dan membuat sistem hukum menjadi luwes. Asas hukum juga dapat mengatasi konflik yang terjadi dalam sistem hukum. Di dalam suatu sistem hukum, tidak pernah dibiarkan terjadi konflik antara unsur-unsur atau bagian-bagian sampai berlarut-larut, karena pada hakekatnya sistem hukum itu sifatnya konsisten dan ajeg. 
Mengenai antinomi dalam sistem dan kaitanya dengan fungsi asas hukum, Mertokusumo (2007 : 25) mengatakan bahwa :

sistem adalah suatu kesatuan yang di dalamnya telah tersedia jawaban atau pemecahannya atas segala persoalan yang timbul di dalam sistem, di mana apabila terjadi konflik antara undangundang dengan undang-undang maka tersedia asas lex posteriori derogat legi priori (kalau terjadi konflik antara undang-undang yang lama dengan yang baru, maka yang berlaku adalah undang-undang yang baru) atau lex superior derogat legi inferiori (kalau terjadi konflik antara peraturan perundang-undangan yang berbeda tingkatnya yang berlaku adalah perundang-undangan yang tertinggi tingkatnya); Kalau terjadi konflik antara undang-undang dengan putusan pengadilan maka tersedia asas res judicata pro veritate habetur (putusan hakim harus dianggap benar); Kalau terjadi konflik antara undang-undang mengenai materi yang bersifat pelengkap dengan hukum kebiasaan, maka hukum kebiasaanlah yang didahulukan.

Ilmu hukum normatif telah menyediakan jawaban terhadap antinomi dalam penerapan peraturan konkrit yang satu dengan peraturan konkrit yang lain, karena dalam penerapan peraturan konkrit dikenal hirarkhi perundangundangan, maka antinomi dalam penerapan peraturan konkrit dapat diselesaikan dengan asas-asas hukum. Namun tidak demikian dengan konflik atau antinomi di antara asas-asas hukum dalam suatu sistem hukum, penyelesaiannya tidak terdapat dalam ilmu hukum normatif.

Penyelesaian antinomi hanya dapat diselesaikan dengan teori hukum.
Teori hukum merupakan ilmu yang bersifat teoretis yang menjawab persoalan-persoalan hukum yang tidak dapat dijawab oleh ilmu hukum dogmatik yang bersifat praktis dan filsafat hukum yang sifatnya abstrak. Tidak seperti pendapat Marwan (2009 : 113) bahwa kebuntuan pemikiran hukum justru disebabkan karena adanya pemisahan antara teori hukum di satu sisi dengan dogmatik hukum dan filsafat hukum di sisi lain.

Antinomi diartikan oleh

Fockema (1983 : 32) sebagai pertentangan antara dua aturan atau lebih yang pemecahannya harus dicari dengan jalan tafsir. Pada dasarnya antinomi merupakan dua hal yang berbeda namun saling melengkapi, oleh karena itu, di dalam menghadapi antinomi, hakim dituntut untuk menciptakan keseimbangan atau keselarasan antara kedua asas tersebut.

Selanjutnya ditegaskan oleh Friedmann (1990 : 2) bahwa :

terjadinya antinomi karena berdasarkan teori, hukum berada di antara filsafat hukum dengan ilmu politik. Ini disebabkan karena pada dasarnya fungsi politik hukum adalah memilih nilai-nilai dan menerapkannya pada hukum yang dicita-citakan sedangkan filsafat hukum merupakan perenungan dan perumusan nilai-nilai hukum. Akibat dari teori hukum terletak di antara filsafat hukum dengan politik hukum, maka timbul persoalan-persoalan baru yang pada satu sisi berkaitan dengan filsafat dan sisi lainnya berkaitan dengan politik yang saling bertentangan.

Sebagai hasil perenungan nilai, maka dalam penerapannya selalu terdapat bentrokan yang tidak dapat dihindarkan, antara asas keadilan dengan tuntutan kepastian hukum. Sebagaimana dikemukakan oleh Immanuel Kant yang 
dikutip oleh van Apeldoorn, (2001: 13) bahwa apabila hukum dijalankan sebagaimana bunyinya, maka akan semakin terdesaklah keadilan (summum ius summa iniuria). Sebaliknya, apabila hukum dijalankan dalam keadaan tertentu, maka dirasakan semakin banyak meniadakan ketidakpastian.

Hukum perdata juga mengandung antinomi, karena hukum perdata mempunyai nilai, yaitu antara nilai kebebasan dengan nilai ketertiban. Di satu pihak menginginkan adanya kebebasan berkontrak, sebaliknya di pihak lain menginginkan adanya ketertiban/keterikatant (asas pacta sunt ser vanda). Antinomi antara unifikasi dengan pluralisme, yaitu sistem hukum yang berlaku bersifat pluralisme, tetapi sebaliknya menghadapi unifikasi atau kesatuan dalam hukum. Asas kepribadian menginginkan adanya kebebasan individu, dan keinginan untuk memperjuangkan kepentingannya sendiri, di pihak lain asas persekutuan menginkan adanya kehidupan bersama, dan dalam kehidupan bersama ini, kepentingan bersama harus ditempatkan di atas kepentingan pribadi.

Antinomi dalam penerapan asas, harus dapat dijalankan secara bersamasama, karena tujuan penerapan asas tersebut mempunyai tujuan yang berbeda dan sifat abstrak dari asas hukum membuat penerapannya didasarkan kepada sistuasi tertentu, sehingga dapat saling melengkapi. Di samping itu asas hukum juga dapat membentuk sistem. Dalam hal pembentukan undang-undang, pembentuk undang-undang selalu dihadapkan pada antinomi antara stabilitas dengan dinamika dalam masyarakat. Dalam hal ini pembentuk undang-undang harus senantiasa memperhatikan kedua asas ini supaya

Yustisia Vol.1 No.1 Januari - April 2012 keduanya dapat berjalan secara bersamasama.

\section{Penemuan Hukum dan Penerapan Asas Legalitas}

Dalam melakukan penemuan hukum, pada dasarnya hakim dihadapkan pada berbagai pertanyaan. Secara umum, terdapat dua pertanyaan yang timbul saat hakim melakukan penemuan hukum, yaitu, apa sesungguhnya yang menjadi peristiwa konkrit atau perkara yang dihadapi oleh pencari keadilan? dan bagaimana hakim sampai pada penetapan bahwa sebuah aturan hukum tertentu dapat dikaitkan dengan fakta-fakta atau peristiwa konkrit tertentu?

Berdasarkan kegiatan hakim dalam proses peradilan, maka pengertian penemuan hukum lebih menunjukkan kepada serangkaian kegiatan hakim untuk menemukan peraturan hukum yang akan diterapkan terhadap peristiwa konkrit yang sudah dikonstatasi atau dinyatakan telah benar-benar terjadi, untuk kemudian dicarikan kualifikasi peristiwa konkrit menjadi peristiwa hukum. Setelah itu dijatuhkan putusan atas peristiwa konkrit yang dihadapkan kepadanya.

Menurut Pontier (2008 : 6), penemuan hukum merupakan reaksi terhadap masalah yang dihadapkan kepadanya. Reaksi ini diarahkan untuk menjawab pertanyaan tentang bagaimana hakim menghadapi peristiwa konkrit yang diajukan kepadanya hingga sampai kepada putusan yang dibuatnya.

Hal ini berkaitan dengan dua hal yang harus diketahui oleh penegak hukum dalam mengadili dan memutuskan perkara di pengadilan. Dua hal yang harus diketahui oleh hakim adalah peristiwa konkrit dan hukum yang akan diterapkan terhadap peristiwa 
konkritnya. Peristiwa konkrit yang menjadi sengketa diketahui melalui proses peradilan, sedangkan pengetahuan tentang hukum itu sudah seharusnya dimiliki oleh hakim sesuai dengan asas ius curia novit.

Penguasaan terhadap sistem hukum merupakan bekal bagi hakim untuk melakukan penemuan hukum, oleh karena itu, hakim yang setiap saat dihadapkan pada suatu perkara untuk diselesaikan, harus mengetahui hukum yang terdapat dalam suatu sistem sesuai dengan asas ius curia novit.

Kegiatan yang dilakukan hakim dalam penemuan hukum terdiri dari kegiatan mengkonstatasi atau menetapkan peristiwa konkrit sebagai peristiwa yang benar-benar terjadi, kegiatan mengkualifikasi yaitu kegiatan menghubungkan peristiwa konkrit tersebut dengan sumber hukum sehingga diketahui peristiwa hukum apa yang telah dilakukan dan kegiatan mengkonstitusi yaitu kegiatan untuk memberi putusan.

Jika dikaitkan dengan kegiatan yang dilakukan hakim dalam proses penemuan hukum, maka asas legalitas itu diterapkan ketika melakukan kegiatan mengkualifikasi peristiwa konkrit menjadi peristiwa hukum dengan cara menghubungkan peristiwa konkrit yang sudah dinyatakan terbukti dengan undang-undang yang menguasainya. Asas legalitas juga diterapkan ketika melakukan kegiatan mengkonsitusi atau kegiatan memberikan hukumnya yang didasarkan kepada undang-undang yang berlaku.

Asas legalitas merupakan akibat pengaruh pandangan positivisme, atau aliran legisme yang umumnya dianut oleh Negara-negara Eropa Kontinental atau pada negara yang mengenal sistem kodifikasi seperti Indonesia. Positivisme memandang undang-undang sebagai hukum yang lengkap dan jelas mengatur tentang suatu peristiwa. Akibatnya, pada negara yang menganut sistem kodifikasi ini, mengenal undang-undang sebagai sumber hukum yang utama.

Dalam pandangan positivisme, tugas hakim pada asasnya hanya menetapkan peristiwa konkritnya dan kemudian menerapkan undang-undang terhadap peristiwa konkritnya. Hakim dalam menyelesaikan suatu perkara, hanya menerapkan undang-undang pada faktanya atau peristiwa yang diajukan kepadanya karena berdasarkan gagasan tersebut hakim tidak lain hanya sebagai corong undang-undang (la bouche de la loi).

Pandangan bahwa hakim hanya sebagai corong undang-undang bertitik tolak pada anggapan, bahwa hakim dilarang untuk menilai undang-undang, karena sebelum membentuk undangundang, pembentuk undang-undang telah mengamati kenyataan kemasyarakatan secara cermat terlebih dahulu, sehingga hukum yang dikodifikasi itu sudah merupakan pencerminan dari hukum yang berlaku dalam masyarakat. Undang-undang sebagai satu-satunya sumber hukum, dianggap cukup jelas dan lengkap yang berisi semua jawaban terhadap semua persoalan hukum.

Perkembangan masyarakat yang disebabkan aspek modernisasi dalam mobilitas sosial, urbanisasi, industrialisasi dan perubahan teknologi yang tidak dapat dihindari dapat menghasilkan membuat hukum tidak dapat mengikuti atau menuntaskan semua kepentingan manusia. Hukum perdata yang pada umumnya bersifat mengatur, lebih memberikan keleluasaan kepada hakim untuk melakukan penemuan hukum. Namun dalam sistem 
hukum perdata itu sendiri juga terdapat hukum yang sifatnya memaksa, seperti pengaturan hak-hak kebendaan dalam Buku Kedua KUH Perdata, hakim dilarang untuk menciptakan hak-hak kebendaan selain dari yang sudah ditentukan oleh undang-undang.

Dalam perkembangannya, sifat memaksa dari Buku Kedua KUH Perdata sudah disimpangi oleh hakim melalui Putusan Hoge Raad tanggal 25 Januari 1929 tentang fidusia, sebagaimana diatur dalam HR Bierbrouwerijarrest: Haan versus $N V$ Heinekens Bierbrouwerij Maatschappij. Dalam HR tersebut ditentukan bahwa peralihan eigendom untuk jaminan dengan constitutum possesorium (fidusia) dibolehkan.

Demikian juga dalam perkara pidana yang sangat ketat menganut asas legalitas ini, akibat perkembangan perilaku kejahatan baru yang tidak diatur dalam KUHP menyebabkan pertumbuhan kejahatan baru, sehingga mau tidak mau harus dilakukan perluasan dan penyimpangan dari asas legalitas untuk memenuhi kebutuhan hukum pidana di luar kodifikasi (Purnomo, 1984 : 10-11)

Hal ini menyebabkan, dalam perkembangannya, hukum pidana juga sudah sering mempersoalkan perbedaan interpretasi, yang bertentangan dengan sistem hukum dari KUHP itu sendiri. Seperti dalam kasus Rizal Ramli yang dijadikan tersangka kasus penghasutan dalam aksi anarkis unjuk rasa penolakan kenaikan harga bahan bakar minyak di Jakarta beberapa waktu yang lalu (Kompas, 13 Maret 2009).

Perbedaan pendapat tentang penafsiran Pasal 160 KUHP tentang Penghasutan, di mana Rizal Ramli mengangap penghasutan yang dituduhkan kepadanya dirasakan

Yustisia Vol.1 No.1 Januari - April 2012 bertentangan dengan Pasal 28, Pasal 28C, 28E, 28F UUD 1945, yang pada dasarnya mengatur tentang kebebasan mengeluarkan pendapat sehingga mengajukan permohonan uji materiil terhadap pasal penghasutan tersebut. Namun menurut Muzakir anggota Tim Revisi KUHP yang mewakili pemerintah dalam sidang uji materiil terhadap Pasal 160 KUH, kegiatan menghasut itu bersifat limitatif dan tidak bisa ditafsirkan secara meluas. Ia juga menilai bahwa tidak ada pertentangan norma antara Pasal 160 KUHP dengan kebebasan seorang untuk menyampaikan pendapat yang dijamin konstitusi

Sebelumnya, terjadi penalaran analogi atas putusan HR pada tanggal 21 Mei 1921 tentang putusan mengenai aliran listrik (Electriciteitsarrest N.J. 1921) yang memutuskan bahwa listrik termasuk barang yang dapat dicuri sebagaimana ditentukan dalam Pasal 362 KUHP. Terhadap putusan ini, para ahli hukum pidana juga terdapat perbedaan pendapat atas penemuan hukum yang dilakukan oleh hakim terhadap delik pencurian tersebut berdasarkan asas legalitas yang terdapat dalam Pasal 1 ayat (1) KUHP.

Menurut Taverne, dalam hukum pidana dibolehkan analogi, sedangkan menurut van Hattum, penafsiran terhadap hukum hanya dilakukan berdasarkan sejarah terbentuknya Pasal 1 ayat (1) KUHP. Sementara Hazewinkel Suringa tidak tegas mengatakan apakah analogi dibolehkan dalam hukum pidana, namun hanya mengemukakan bahwa Pasal 1 ayat (1) KUHP memerlukan kepastian hukum (rechtzekerheid) dan persamaan hukum (rechtsgelijkheid) dan tidak menghendaki suatu penafsiran luas dari ketentuan hukum pidana (Prodjodikoro, 1986 :46). 
Dalam membicarakan penalaran analogi, terdapat dua paham atau aliran yang sangat berbeda dan bertentangan satu sama lainnya. Paham klasik yang dipelopori oleh Simons, berpendapat bahwa untuk menjaga kepastian hukum, maka penafsiran analogi tidak dibolehkan. Sebaliknya, paham modern yang dipelopori oleh Pompe, antara lain mengatakan bahwa asas legalitas dibuat pada abad 18 yang bertujuan mencegah kesewenang-wenangan penguasa, sedangkan sekarang telah ada ajaran trias politika di mana kekuasaan negara dibagi dalam beberapa badan sehingga terhindar dari tindakan kesewenangwenangan dari penguasa.

Paham modern berpendapat bahwa hukum dan undang-undang sifatnya statis sedangkan masyarakat adalah dinamis sehingga hukum dan undangundang sering ketinggalan dari perkembangan masyarakat (het recht hinkt achter de feiten aan) oleh karena itu, analogi itu dapat diterapkan untuk menjaga agar hukum pidana tidak tertinggal dengan perkembangan masyarakat. Namun karena analogi dilarang maka hakim mengambil keputusannya berdasarkan pada penafsiran ekstensif.

Antara penalaran analogi dengan penafsiran ekstensif pada dasarnya mempunyai kemiripan satu sama lain, karena analogi sifatnya mempersamakan suatu peristiwa yang belum ada pengaturannya dengan peristiwa yang mirip dengan peristiwa yang sudah ada peraturannya. Penalaran analogi digunakan apabila menghadapi peristiwa-peristiwa yang analog atau mirip, tidak hanya sekedar mirip juga apabila kepentingan masyarakat menuntut penilaian yang sama, dengan peristiwa yang ada peraturannya. Penafsiran ekstensif merupakan

Yustisia Vol.1 No.1 Januari - April 2012 penafsiran atau menjelaskan suatu peristiwa yang belum diatur yang sifatnya memperluas yang melampaui batas yang diberikan oleh penafsiran gramatikal sehingga peraturan yang dijelaskan itu dapat diterapkan terhadap peristiwa yang sudah diatur oleh undang-undang.

Problematik penerapan asas legalitas umumnya terdapat dalam perkara pidana karena berkaitan dengan kedudukan yang tidak seimbang antara tersangka/terdakwa dengan aparat hukum yang berkepentingan, sehingga dikuatirkan terjadi tindakan sewenangwenang dari aparat hukum.

Menurut Djokosutono dalam bukunya Prasetyo (2005 : 9) salah satu perbedaan antara hukum pidana dengan hukum perdata dilihat dari kedudukan pihak yang berkepentingan, yaitu dalam hukum privat (perdata) mengatur hubungan yang kedudukannya sejajar, sedangkan hukum publik mengatur kedudukan yang tidak sederajat, yaitu antara pemerintah dengan pelaku tindak pidana.

Dengan menghadapkan seseorang karena dianggap telah melakukan perbuatan yang telah ditentukan dalam KUHP, sesuai dengan asas legalitas, maka diharapkan tindakan sewenangwenang dari pihak aparat dapat dihindari. Dengan mengingat tujuan dari asas legalitas yang dianut oleh hukum pidana adalah kepastian hukum, maka hukum pidana tidak boleh berlaku surut dalam arti tidak berlaku bagi seseorang yang melakukan perbuatan pidana sebelum undang-undang hukum pidana berlaku.

Penerapan asas legalitas dalam sistem peradilan pidana juga sangat berkaitan dengan sistem penghukuman dalam hukum pidana itu sendiri, yang menurut Hadisuprapto (3009 : 107), 
upaya penanggulangan kejahatan melalui jalur penal lebih menitik beratkan pada sifat represif, berupa penumpasan, pembrantasan dan penindasan setelah kejahatan terjadi. Senada dengan pengertian hukum pidana yang pada dasarnya berasal dari kata pemidanaan atau suatu keadaan nestapa, yang artinya suatu hukuman yang diberikan oleh suatu institusi kemudian diserahkan kepada oknum tertentu untuk mendatangkan nestapa atau siksaan.

Kecenderungan manusia yang mempunyai sifat ingin menang sendiri, sehingga sering melakukan tindakan main hakim sendiri (eigenrichting) turut memicu lahirnya penerapan asas legalitas, meskipun penegakan hukum melalui proses peradilan merupakan salah satu cara untuk mencegah terjadinya eigenrichting.

Tindakan menghakimi sendiri merupakan tindakan untuk melaksanakan hak menurut kehendaknya sendiri yang bersifat sewenang-wenang, tanpa persetujuan pihak lain yang berkepentingan sehingga akan menimbulkan kerugian (Mertokusumo, $2006: 3$ ).

\section{Antinomi dalam Penerapan Asas Legalitas}

Adanya asas legalitas yang diatur dalam Pasal 1 KUHP menyebabkan hukum pidana bersifat memaksa. Sifat memaksa dalam hukum pidana yang sudah mengatur sedemikian rupa mengenai batasan delik dan kaedah sanksi, membuat hakim pidana tidak dapat menciptakan delik baru maupun sanksi-sanksi baru di luar delik ataupun sanksi yang sudah ditentukan dalam KUHP Pidana.

Sebagai asas, penerapan asas legalitas dalam sistem peradilan pidana harus tetap dijalankan meskipun di

Yustisia Vol.1 No.1 Januari - April 2012 dalam penerapannya terdapat antinomi atau konflik dengan beberapa asas-asas umum hukum acara seperti asas rechtsweigering, asas mengadili menurut hukum, dan asas kebebasan hakim dalam UU Kekuasaan Kehakiman. Hal ini berarti bahwa penerapan asas legalitas dalam KUHP tetap dapat eksis bersamasama.

Penerapan asas rechtweigering yang terkandung dalam Pasal 10 ayat (1) UU Kekuasaan Kehakiman, didasarkan kepada perkembangan pemikiran atau gagasan bahwa semua materi hukum yang telah diatur secara tuntas dan menyeluruh di dalam undang-undang, tidak dapat dipertahankan lagi mengingat semakin kompleksnya kepentingan masyarakat, sehingga tidak mungkin dicakup dalam suatu undangundang, sedangkan penerapan asas legalitas didasarkan kepada pemikiran bahwa semua materi hukum sudah diatur sedemikian rupa dalam undang-undang sehingga mencakup keseluruhan kepentingan manusia secara tuntas.

Antinomi antara asas legalitas dengan asas rechtweigering terjadi ketika peristiwa konkrit yang diajukan kepada hakim, tidak diatur dalam perundang-undangan, ataupun tidak terdapat jawabannya dalam perundangundangan. Oleh karena itu dalam penerapannya, hakim harus melakukan penafsiran teleogis terhadap berlakunya kedua asas tersebut.

Penerapan asas rechtweigering bertujuan untuk mengisi kekosongan hukum, sehingga tujuannya tercapai, yaitu ketertiban dalam masyarakat, sedangkan asas legalitas bertujuan untuk menghindari kesewenang-wenangan dari penguasa dan untuk menjamin kepastian hukum.

Putusan hakim sebagai hasil akhir dari kegiatan penemuan hukum harus 
memenuhi unsur Idee des Recht yang dikemukakan Radbruch (1973 : 171179) yaitu kepastian hukum (Rechtssicherheit), kemanfaatan (Zweckmassigkeit) dan keadilan (Gerechtigkeit) secara proporsional. Dengan menerapkan asas legalitas dan asas rechtweigering secara bersamasama, maka putusan hakim tersebut telah memenuhi unsur kepastian hukum sekaligus unsur keadilan dan bermanfaat bagi pihak-pihak yang berkepentingan.

Jika dikaitkan dengan situasi undang-undangnya tidak jelas atau tidak dapat mencakup peristiwa konkrit yang dihadapkan kepadanya, maka berdasarkan asas rechtweigering harus diterapkan dengan cara menjelaskan atau menafsirkan undang-undang sehingga dapat diterapkan terhadap peristiwanya. Penerapan asas rechtweigering berkaitan dengan asas ius curia novit, yaitu asas yang menggangap hakim tahu semua hukum.

Asas ius curia novit mengharapkan hakim sebagai pejabat yang melakukan kekuasaan kehakiman, mempunyai pengetahuan hukum yang berlaku dalam masyarakat sehingga dapat mengadili dan memutuskan semua perkara yang dihadapkan kepadanya. Apabila hakim tidak menemukan hukum dalam undang-undang atau hukum tertulis, maka hakim wajib menggali, mengikuti dan memahami nilai-nilai hukum dan rasa keadilan yang hidup dalam masyarakat (Pasal 5 ayat (1) dengan Pasal 19 UU Kekuasaan Kehakiman).

Antinomi penerapan asas legalitas juga terjadi ketikia dihadapkan dengan asas kebebasan hakim yang merupakan salah satu prinsip penting penyelenggaraan peradilan dalam suatu negara hukum. Asas legalitas mengharuskan hakim tunduk kepada

Yustisia Vol.1 No.1 Januari - April 2012 undang-undang dalam melakukan penemuan hukum, sebaliknya asas kebebasan hakim menginginkan hakim bebas dan tidak terikat kepada pihak ekstra judisial.

Menurut Pasal 1 ayat (3) Perubahan Ketiga UUD 1945, Negara Indonesia adalah negara hukum. Menurut Budiardjo (1982 :50) sebagai salah satu ciri-ciri negara hukum, maka prinsip penyelenggaraan kekuasaan kehakiman yang merdeka tersebut, harus dijamin secara konstitusional.

Untuk dapat menerapkan asas legalitas dan asas kebebasan hakim secara bersama-sama, harus diketahui makna dari kebebasan hakim itu sendiri. Pada dasarnya, tujuan dari kebebasan hakim yang merupakan sifat pembawaan dari setiap peradilan dalam mengadili dan memutuskan perkara adalah agar pengadilan dapat menunaikan tugasnya dengan sebaik-baiknya sehingga dapat memberikan putusan yang berdasarkan kebenaran, keadilan dan kejujuran.

Dalam Pasal 3 UU Kekuasaan Kehakiman tidak disebutkan batasan dari kebebasan hakim tersebut selain hanya menyebutkan kecuali dalam hal-hal sebagaimana dimaksud dalam UUD 1945 (Pasal 3 yat (2) UU Kekuasaan Kehakiman). Berdasarkan Pasal 3 UU Kekuasaan Kehakiman, jo Pasal 4 ayat (1) UU Kekuasaan Kehakiman bahwa pengadilan mengadili menurut hukum, maka pada dasarnya kebebasan hakim itu dibatasi oleh sistem hukum yang berlaku berdasarkan Pancasila dan UUD 1945.

Kebebasan hakim yang bersifat tidak mutlak tersebut dilakukan dengan kebebasan untuk menafsirkan hukum dan mencari dasar dasar hukum serta asas-asas yang menjadi landasan dari setiap putusannya melalui perkaraperkara yang dihadapkan kepadanya 
sehingga putusannya mencerminkan perasaan keadilan rakyat Indonesia.

Jika dihubungkan dengan tugas dan fungsi hakim sebagai penegak hukum dan keadilan, maka pembatasan kebebasan hakim ini dimaksudkan agar hakim dalam mengadili dan menyelesaikan sengketa tetap berdasarkan hukum yang berlaku. Keadilan yang diberikan hakim dalam putusannya harus dibangun menurut hukum, bukan sekedar kehendak hakim yang bersangkutan.

Penerapan asas kebebasan, diterapkan pada kegiatan mengkonstatasi peristiwa yang disengketakan ketika hakim menilai dalil-dalil atau bantahan juga kebebasan untuk menilai alat-alat bukti yang diajukan oleh pihak-pihak. Penerapan asas kebebasan hakim ini juga diterapkan pada kegiatan mengkualifikasi dengan memberikan kebebasan kepada hakim bebas untuk mempergunakan semua metode penemuan hukum dalam menafsirkan undang-undang.

Penerapan asas legalitas dengan asas mengadili menurut hukum dapat saling melengkapi. Dengan melihat tujuan penerapan asas legalitas adalah untuk menjamin kepastian hukum, maka penerapan asas mengadili menurut hukum adalah untuk mengisi kekosongan hukum. Jadi dalam menerapkan asas legalitas, hakim tetap memperhatikan kepastian hukum, sedangkan dalam menerapkan asas mengadili menurut hukum, hakim lebih dapat menggali rasa keadilan yang tumbuh dan berkembang dalam masyarakat sehingga putusannya dapat memberikan keadilan dan kemanfaatan bagi pihak-pihak yang berkepentingan.

Jika berpedoman pada asas lex posteriori derogate legi priori, yang disebut dalam ilmu hukum dogmatik, maka asas legalitas dalam Pasal 1 ayat (1) KUHP yang isinya bertentangan dengan asas mengadili menurut hukum, asas rechtweigering dan asas kebebasan hakim dalam UU Kekuasaan Kehakiman, maka asas legalitas tersebut harus dilumpuhkan, namun karena hukum itu dibuat demi kepentingan manusia maka semua asas yang terdapat dalam peraturan konkrit itu, dapat disimpangi melalui penafsiran teleologis/sosiologis yaitu ditafsirkan berdasarkan tujuan pembentuk undangundang yang disesuaikan dengan perkembangan masyarakat. Jadi semua asas ini dapat tetap berlaku secara bersama-sama dan saling mengisi.

Dalam melakukakan kegiatan penemuan hukum, hakim harus memperhatikan asas legalitas, yang menginginkan hakim wajib mengadili berdasarkan undang-undang, namun berbenturan dengan asas hakim mengadili menurut hukum, di mana hukum diartikan sebagai hukum yang tertulis dalam undang-undang dan hukum tidak tertulis, di samping itu terdapat asas kebebasan hakim yang memberikan kebebasan bagi hakim untuk melakukan penemuan hukum.

Asas legalitas dapat dijalankan bersama-sama dengan asas rechtweigering, di mana asas legalitas dijalankan untuk menghindarkan kesewenang-wenang penguasa ketika menghadapkan seseorang untuk diadili. Ini artinya, seseorang boleh dihadapkan ke pengadilan apabila seseorang itu, telah dianggap melanggar suatu perbuatan yang dilarang oleh undangundang. Di samping itu, penerapan asas legalitas, didasarkan kepada fungsi asas legalitas tersebut untuk menjamin kepastian hukum (Rechtssicherheit).

Penerapan asas rechtweigering, didasarkan kepada tugas dan fungsi 
hakim sebagai penegak hukum dan keadilan, sehingga wajib mengadili semua perkara yang diajukan kepadanya meskipun terhadap perkara tersebut, undang-undangnya tidak jelas atau tidak lengkap.

Asas hakim mengadili menurut hukum, dijalankan dengan mengingat bahwa undang-undang dibuat untuk melindungi kepentingan manusia, oleh karena kepentingan manusia itu selalu berkembang maka hukum juga harus berkembang sehingga selalu dapat melindungi kepentingan manusia.

Asas kebebasan hakim diterapkan ketika hakim berhadapan dengan peristiwa yang tidak jelas atau belum ada pengaturannya dalam undang-undang, sehingga dengan kebebasan hakim untuk menafsirkan undang-undang, maka hakim dapat memberi putusan yang dirasakan adil ((Einzalfallgerechtigkeit).

\section{E. Kesimpulan}

Penerapan asas legalitas sering menimbulkan antinomi dengan asas mengadili menurut hukum, asas rechtweigering dan asas kebebasan hakim. Namun sebagai asas, ketiga asas tersebut harus dijalankan secara bersama-sama dengan asas legalitas karena :

1. dalam menerapkan asas legalitas, hakim tetap memperhatikan kepastian hukum, sedangkan dalam menerapkan asas mengadili menurut hukum, asas rechtweigering dan asas kebebasan hakim, hakim dituntut selalu menggali rasa keadilan yang tumbuh dan berkembang dalam masyarakat sehingga putusannya dapat memberikan keadilan dan kemanfaatan bagi pihak-pihak yang berkepentingan.

2. asas hakim mengadili menurut hukum, dijalankan dengan mengingat bahwa undang-undang dibuat untuk melindungi kepentingan manusia, oleh karena kepentingan manusia itu selalu berkembang maka hukum juga harus berkembang sehingga selalu dapat melindungi kepentingan manusia.

3. penerapan asas rechtweigering, didasarkan kepada tugas dan fungsi hakim sebagai penegak hukum dan keadilan sehingga hakim wajib mengadili semua perkara yang diajukan.

4. asas kebebasan hakim diterapkan ketika hakim berhadapan dengan peristiwa yang tidak jelas atau belum ada pengaturannya dalam undangundang, dengan kebebasannya maka untuk ketidaklengkapan atau ketidakjelasan undang-undang dapat dilengkapi atau dijelaskan sehingga putusannya dirasakan adil (Einzalfallgerechtigkeit) dan bermanfaat. 


\section{DAFTAR PUSTAKA}

Andreae, Fockema,1983. Kamus Istilah Hukum, Belanda-Indonesia, Cetakan Pertama, Jakarta : Binacipta.

Budiardjo, Mariam, 1982. Dasar-Dasar Ilmu Politik, Jakarta : , Gramedia.

Friedmann, W., 1990. Teori dan Filsafat Hukum, Telaah Kritis atas Teori-Teori Hukum (Susunan Pertama) Terjemahan Muhamad Arifin, Jakarta : Radja Grafindo Persada.

Hadisuprapto, Paulus, 2009. "Peradilan Anak Restoratif; Prospek Hukum Pidana Anak Indonesia", Jurnal Yuridika, Volume 24, Nomor 2 Mei-Agustus 2009 Surabaya : Universitas Airlangga.

Kanisius, 1990, Ensiklopedia Umum cetakan kedelapan, Yogyakarta : Kanisius.

Marwan, Awaludin, 2009. "Dekonstruksi Teks Hukum; Ketika Derrida Memikirkan Hukum", Jurnal Konstitusi, Volume 6 Nomor 4, November 2009, Jakarta : Mahkamah Konstitusi.

Mertokusumo, Sudikno, 2006. Hukum Acara Perdata Indonesia, Yogyakarta: Liberty.

-,2007. Penemuan Hukum Sebuah Pengantar, Edisi Kedua, Cetakan Keempat, Yogyakarta : Liberty.

Poernomo, Bambang, 1984. Pertumbuhan Hukum Penyimpangan di Luar Kodifikasi Hukum Pidana, Jakarta : Bina Aksara.

Pontier, J.A., 2008. Penemuan Hukum,(Terj. Arief Sidharta), Cetakan Kesatu, Bandung : Jendela Mas Pustaka.

Prasetyo, Teguh, 2005. Hukum Pidana Materiil, Yogyakarta : Kurnia Kalam2005

Prodjodikoro, Wirjono, 1986. Asas-Asas Hukum Pidana di Indonesia, Bandung : PT Eresco.

Radbruch, Gustav , 1973, Rechtsphilosophie, K.F. Koehler, Stuttgart.

van Apeldoorn, L.,J., 2001. Pengantar Ilmu Hukum, (terj. Oetarid Sadino), Cetakan Keduapuluh sembilan, Jakarta : Pradnya Paramita.

Uji Materiil terhadap Pasal 160 KUHP Kompas 13 Maret 2009.

Yustisia Vol.1 No.1 Januari - April 2012

Antinomi Dalam Penerapan... 157 